\title{
Access to Trade Credit by Informal Firms in Ghana: Does Locating in Industrial Cluster and Holding Production/Supply Contract Matter?
}

\author{
Stanley Kojo Dary \\ Department of Economics and Entrepreneurship Development, University for \\ Development Studies, Box 520, Wa Campus, Ghana.Email:sdary@uds.edu.gh \\ DOI//http://dx.doi.org/10.4314/gjds.v15i2.8
}

\begin{abstract}
The paper examines the effect of locating in industrial cluster and holding production/ supply contract on access to trade credit by informal firms in Ghana. It employs data from the 2013 World Bank survey of informal firms in Ghana. The results show that trade credit is the most important external source of financing working capital for firms in the informal sector. Binary probit was employed in the econometric analysis. Controlling for firm characteristics, financial characteristics, firms' largest owners' characteristics, industrial sector and geographical location, the results show that both locating in industrial cluster and holding production/supply contract significantly increase access to trade credit by informal firms. Other variables significantly associated with access to trade credit include firm age, number of owners, ownership of location, access to loans from banks and friends, and firms' largest owners' characteristics - formal employment status, marital status and educational status. Based on the results, policies focused on promoting the development of industrial clusters can help informal firms to mitigate their credit constraint through increased access to trade credit. Informal firms can also mitigate their credit constraint via trade credit by obtaining production/supply contracts.
\end{abstract}

Keywords: Trade Credit, Informal Firms, Industrial Cluster, Supply Contract, Probit, Ghana JEL Classifications: L66, G32, D22

\section{Introduction}

It is well documented in literature that trade credit is an important source of financing working capital among non-financial firms (e.g., Emery, 1984; Long, Malitz and Ravid, 1993; Cuevas, Fafchamps, Hanson, Moll \& Srivastava, 1993; 
Petersen \& Rajan, 1997; Wilson \& Summers, 2002; García-Teruel \& Martínez-Solano, 2010; Carvalho \& Schiozer, 2011). As a source of financing, trade credit comes in two forms: (1) supplier credit and (2) prepayment/advanced payment. Supplier credit is trade credit received from input suppliers upstream; this is generated when firms receive inputs from suppliers upstream and payment is delayed or deferred to a later date ( $\mathrm{Ng}$, Smith \& Smith, 1999; García-Teruel \& Martínez-Solano, 2010; Carvalho \& Schiozer, 2015). Prepayment/ advanced payment is trade credit received from customers downstream who make payment preceding the delivery of goods (e.g., Schwartz, 1974; Ferris, 1981; Fafchamps, Pender and Robinson, 1995; Mateut, 2014). Prepayment or advanced payment is also described as reverse trade credit in the literature because customers are advancing credit to suppliers (see e.g., Daripa \& Nilsen, 2011; Mateut, 2014). While input suppliers upstream assumes greater proportion of risk when it comes to supplier credit, with advanced payment, buyers assume the greater proportion of the risk (Cuevas et al., 1993; Ng et al., 1999; Klapper, Laeven \& Rajan, 2012). According to Issakson (2002), the incidence of demand for advance payment is common among informal firms relative to formal ones. Advance payment is also common among African microenterprises (Fafchamps et al., 1995).

In general, trade credit is a short-term financing arrangement with 30 days average credit period commonly reported around the globe (see for instance, Fafchamps et al., 1995; Petersen \& Rajan, 1997; Ellingsen et al., 2016). Trade credit is a non-conventional type of credit, as it is not available to firms outside a trading relationship. Trade credit is tied to sale or purchases of goods and hence it is a restricted type of short-term financing (Emery, 1984). Most firms are engaged in extending and receiving trade credit, this is captured under accounts receivable and accounts payable respectively in firms' balance sheets. Firms have various motives for engaging in trade credit activity; these are discussed in Section 2.

Access to trade credit by firms in the informal sector is less understood generally and in Ghana in particular, due to limited empirical work. Studies on access to credit by informal firms are generally centered on formal credit from traditional financial intermediaries such as banks and microfinance institutions (e.g., Akoten, Sawada \& Otsuka, 2006; Clarke, Cull \& Peria, 2006). However, trade credit may be an important source of working capital for firms in the informal sector in developing countries who generally has less access to credit from financial markets, due to credit rationing (e.g., Petersen \& Rajan, 1997; Ogawa, Sterken \& Tokutsu, 2013). In Ghana for instance, Cuevas et al.'s (1993) study on enterprise finance show trade credit is an important source of working capital among small manufacturing firms. Also, there appear to be a bias in the empirical literature on trade credit towards 
formally registered small, medium and large firms (Petersen \& Rajan, 1997; Ng et al., 1999; Mateut \& Zanchettin, 2013; Saito \& Bandeira, 2010; Klapper et al., 2012).

The purpose of this paper is thus to examine access to trade credit by firms in the informal sector in Ghana. The paper specifically examines the research question, does locating in industrial cluster and holding production/supply contract facilitate access to trade credit among informal sector firms in Ghana? In so doing, the paper contributes to the understanding of trade credit activity in the informal sector in a developing country context, particularly the role of industrial clusters and production/supply contracts. The rest of the paper is organised as follows: Section 2 reviews the theories of trade credit, the research methods employed are presented in Section 3, Section 4 presents and discusses the empirical results, and Section 5 is the conclusion and policy suggestions.

\section{Access to Trade Credit: Theoretical Overview}

Various theories have been put forward to explain why a non-financial firm will extend credit to another non-financial firm. These theories are broadly put into three categories: (1) transaction/operation, (2) financing, and (3) commercial theories. There are supply sided and demand sided perspectives of these theories. From the supply side, the financing theory posits that financially stronger firms will extend credit to financially weaker firms (Schwartz, 1974). Firms have information advantage over traditional financial institutions due to their frequent interaction with their trading partners. They can thus extend credit at lower transaction cost than banks (Emery, 1984; Petersen \& Rajan, 1997). Also, firms with access to financial markets may borrow and extend credit to firms they have trading relationship with, who may be rationed from financial markets (Schwartz, 1974). This is the redistributive view of trade credit (Meltzer, 1960; Ogawa et al., 2013). The transaction cost theory states that firms may extend credit to other firms as a way of reducing transaction costs (Schwartz, 1974; Ferris, 1981). For instance, frequent visits to the bank to make payments and holding high inventories can increase transaction costs and extending trade credit can mitigate that (Ferris, 1981; Petersen \& Rajan, 1997).

There are several theories that falls under the commercial theories - marketing, quality guarantee, tax, price discrimination and long-term relationship theories. The quality guarantee theory states that firms extend trade credit as a way of allowing customers to verify the quantity and quality of goods supplied before making payment and in so doing, it facilitates sales (Smith, 1987; Long et al., 1993; Fafchamps et al., 1995). This is especially important for firms and /or products 
without established reputation in the market (ibid). Firms can use trade credit to promote sales and market their products (Nadiri, 1969; Wilner, 2000). Offering trade credit is a way of gaining market share especially in competitive markets. Trade credit is also a useful tool for market entry by new firms or for new products introduced by incumbent firms (Cheng \& Pike, 2003; Wilson \& Summers, 2002; Van Horen, 2005). Extending trade credit to customers is a way of building longterm relationship with customers, which may yield benefits over time (Nadiri, 1969). Building long-term relationship through trade credit is expected to prevent customers switching to competitors (Cheng \& Pike, 2003; Van Horen, 2005). Firms may also extend trade credit as a way of deferring tax liabilities and increasing cash flow (Brick \& Fung, 1984; Brennan, Maksimovic \& Zechner, 1988). Because price discriminatory practices are prohibited in many countries, extending trade credit is an indirect mechanism to price discriminate among customers (Schwartz \& Whitcomb, 1978; Petersen \& Rajan, 1997). Offering the same trade credit terms to low-quality customers and high-quality customers is a price discrimination in favor of the latter (Petersen \& Rajan, 1997). In the context of advanced payment type of trade credit, marketing, quality guarantee and price discrimination theories have limited explanatory power from the supply side.

From the demand side, financially weaker firms may depend on financially stronger trading partners to finance their operations, per the financing theory. Firm without access to financial markets or firms that are credit rationed may tend to demand trade credit (Schwartz, 1974; Lin \& Chou, 2015). Firm may tend to demand trade credit from their suppliers for transaction cost or operational reasons. It allows simplification of transactions and thus reduces transaction costs (Ferris, 1981). For quality verification purposes, firms may demand trade credit to allow time to verify product quantity and quality before making payment (Long et al., 1993; Smith, 1987). A firm may demand trade credit from input suppliers/customers if it has market power in the industry (Van Horen, 2005; Fabbri \& Klapper, 2008). In general, the tax theory, marketing, long-term relationship and price discrimination theories have limited relevance in explaining demand for trade credit from suppliers upstream or customers downstream.

The discussion in this section thus far, concerns the theories or motives for supply of and demand for trade credit. In relation to access to trade credit however, this paper draws on contract theory. According to Brousseau and Glachant (2002, p.3), "a contract is an agreement under which two parties make reciprocal commitments in terms of their behavior". Contrary theory occupies an important space in the trade credit literature (Fafchamps et al., 1995; Isaksson, 2002; Wilson \& Summers, 2002; Klapper et al., 2012). The terms in trade credit contracts are of two types: net terms 
and two-part terms. Net terms (e.g., net 30) specify the full amount to be paid at the due date whilst two-part terms (e.g., 2/10 net 30) involve a stated discount if early payment is made before the due date (Long et al., 1993; Ng et al., 1999). Trade credit contracts are simple in nature, such as an invoice. A typical trade credit contract will contain identifying information of the transacting parties, the goods involved and their monetary value, discounts (if any), the due date, interest (if any) and penalties for late payment such as late fees (if any) (Wilson and Summers, 2002; Dary, 2017). The interest charged on trade credit remains a puzzle. The idea of costly trade credit relative to bank credit is often grounded on implicit interest, computed using discount rate offered in two-part trade credit terms. However, the empirical evidence suggests trade credit is largely cheaper relative to bank credit (Cuevas et al., 1993; Chandler, 2009; Ellingsen et al., 2016; Cheng \& Pike, 2003; Burkart \& Ellingsen, 2004). Aside financing motive for trade credit, it may be counterintuitive to charge interest on trade credit when the motives involved are transactional/ operational and commercial motives (Dary, 2017).

In trade credit contracting like any financial contract, the credit quality or credit worthiness of the firms involved as well as the contracting or institutional setting within which trade credit contracts are made and executed are important considerations. The institutional setting conveys information about risk, uncertainty and effectiveness of contract enforcement mechanisms. Contract compliance or effectiveness of contract enforcement mechanisms is essential in trade credit transactions. Fafchamps et al. (1995) states that contractual obligations will be respected when enforcement mechanisms are effective in penalizing contract breaches. ${ }^{21}$ Firms rely on informal enforcement mechanisms such as goodwill trust, reputational damage and threat of refusal of future business (Dyer, 1997; Fafchamps et al., 1995). The courts are usually a last resort in dealing with trade credit contractual breaches (Cuevas et al., 1993). In this paper, holding supply contract and locating in a business cluster can enhance trade credit contract compliance through reduction in information asymmetry via enhanced screening and monitoring due to close proximity and repeated interaction. These factors should thus increase firms' access to trade credit from suppliers upstream and/or customers downstream.

\section{Business Clusters and Access to Trade Credit}

Foghani, Mahadi, and Omar (2017, p.2) defined clusters as "the agglomeration of inter-related firms and related institutions". Alternatively, "clusters are a

21 In Ghana, the Contract Act (1960), Act 25, provides the legal framework for contracting (see http://laws. ghanalegal.com/acts/id/18) 
geographic concentration of interconnected companies and industries" (Wheelen \& Hunger, 2012, p. 140). Among other things, business clusters increase access to employees, suppliers, specialised information and complementary products (Porter, 1998). It has been shown in the literature that location in business clusters facilitate the use of trade credit in interfirm trade. Long and Zhang (2011) states that clustering reduces the geographical distance among firms, increasing the use of trade credit in interfirm trade. The high use of trade credit in industrial clusters reduce the dependence of firms on formal financial intermediaries for working capital. Long and Zhang (2011) further argue that the closer and repeated interaction among firms within industrial clusters reduce information asymmetry and builds trust at the same time between firms and their customers upstream and suppliers downstream, thus reducing the transaction cost of trade credit activity. Ruan and Zhang (2008), Dinh, Rawski and Zafar (2013), and Zhang (2016) all emphasized that proximity and frequent interactions among firms within industrial clusters foster the development of social networks, leading to increased use of trade credit and less reliance on formal financial intermediaries.

Hypothesis 1: Firms located in industrial clusters are more likely to receive trade credit from input suppliers upstream and /or advanced payment from customers downstream.

\section{Production/Supply Contracts and Access to Trade Credit}

Access to trade credit from input suppliers upstream and customers downstream may increase with holding a contract to produce/supply goods and services. Yang and Birge (2013) states that trade credit is an integrated component of supply contracts. This suggest that, if a firm is able to obtain production/supply contract, the likelihood of obtaining trade credit from the other party (or parties) to the supply contract is high. The incidence and magnitude of trade credit is expected to be high when goods involved in the production/supply contract are specialised or idiosyncratic goods, requiring that the producer/supplier makes asset-specific investment. For idiosyncratic or specialised goods, firms may require customers who place orders to make some advance payment before production commences as a way of dealing with seller uncertainty (Mateut, 2014; Mateut \& Zanchettin, 2013). This is because the value of the goods will be lower in an alternative use should the buyer fail to make good his/her promise.

According to Mateut (2014), the need to incentivise a producer to supply a good gives rise to prepayment, especially from financially capable downstream firms. Doing so will ensure timeliness of production and prevent delays in production/ 
supply (Daripa \& Nilsen, 2011). Mateut and Zanchettin (2013) study among French firms suggest that advanced payment can lower seller uncertainty. In their study, Yang and Birge (2013) concludes trade credit act as a risk-sharing mechanism, distributing operational and financial risks among firms in supply chains. The incidence and magnitude of trade credit is also expected to be high when the supplier faces low or no competition. Therefore, customers may have to make advance payment to ensure adequate and timely delivery of goods to smoothen production or consumption. A case can also be made for increased access to trade credit from input suppliers through supply contracts. The fact that a firm is holding a supply contract suggest that the firm has reputation in the market and is of high credit quality, capable of carrying out contractual obligations. The supply contract itself can serve as implicit guarantee for accessing trade credit from input suppliers.

Hypothesis 2: Firms that hold production/supply contracts are more likely to receive trade credit from input suppliers upstream and /or advanced payment from customers downstream.

\section{Research Methods}

\section{Data Description and Variables}

This paper employs cross-sectional data from the 2013 World Bank survey of informal firms in Ghana. Firms designated as informal firms consist of firms that are unregistered. In the survey, 729 firms were sampled via stratified random sampling procedure. ${ }^{22}$ The respondents to the questionnaire were the owners and top managers of the sampled firms. Data on access to trade credit and the explanatory and control variables are extracted from the survey. Because some firms have missing observations on the variables, the econometric analysis is based on complete cases (Little and Rubin, 2002). Description of the data is presented in Section 4 .

The variables, description and measurement are summarised in Table 1 . In this paper, a firm has access to trade credit (TC) if the firm received trade credit from input suppliers upstream and /or customers downstream for the past year. In the questionnaire, firms were asked if they financed their operations using credit from suppliers or advances from customers. This thus form the basis for the definition put forward for the dependent variable. TC is therefore binary, 1 if a firm received trade credit from input suppliers upstream and /or customers downstream for the past year and o otherwise. The data does not cover the amount of trade

22 For more information on the methodology, see http://www.enterprisesurveys.org/methodology 
credit received and thus numerical based measures such as accounts receivables or advances received employed in other studies (e.g., Petersen \& Rajan, 1997; Fafchamps, 2000; Mateut, 2014; Dary \& James, 2017) cannot be implemented. The explanatory variables, locating in an industrial cluster (CLUSTR) and holding production/supply contract (CNTRACT) are also binary. If a firm is located in a industrial cluster, it is assigned 1, otherwise o. Firms that produce/supply under contract are assigned the value 1 and o otherwise.

The paper controls for a number of variables relating to firm, financial, owner, industry and location characteristics that may affect access to trade credit. Natural logarithm of firm age, natural logarithm of firm size, number of owners of firm and ownership of business location are included to control for firm characteristics. Traditionally, firm age and firm size has been used as proxy for firm reputation and credit quality (e.g., Alarcón, 2011; Petersen \& Rajan, 1997; Fisman \& Raturi, 2004). It is expected that, because older firms have existed long enough to develop reputation and build relationship with other firms, they will have better access to trade credit. Empirically, Petersen and Rajan (1997), Kihanga, Lensink, Lutz and Hermes (2010), and García-Teruel and Martínez-Solano (2010) have found older firms to receive more trade credit while Fisman and Raturi (2004) and Kwenda and Holden (2014) found no relationship. Firm size is linked to access to trade credit. All things being equal, larger firms have high reputation and credit quality and are thus more likely to receive trade credit from input suppliers upstream and customers downstream relative to smaller firms. This is corroborated by a number of studies (e.g., Petersen \& Rajan, 1997; Fisman \& Raturi, 2004, García-Teruel \& Martínez-Solano, 2010). Another dimension is that, larger firms may have the financial endowment to finance their operations and may depend less on their suppliers and customers to finance their operations. For instance, Kihanga et al. (2010) found small firms to receive more trade credit in Tanzania.

It expected that access to trade credit will increase with the number of owners. The more the number of owners, the more likely suppliers and customers will ascribe greater reputation and credit worthiness to the firm and thus will be more inclined to extend trade credit to the firm. Ownership of location where the firm operates can serve as collateral or implicit guarantee, thus increasing access to trade credit. Trade credit may serve as a substitute or complement to other alternative sources of financing working capital. While some empirical evidence supports substitution relationship between trade credit and bank loan (e.g., Garcia-Teruel \& MartinezSolano, 2010; Kwenda \& Holden, 2014), other empirical evidence supports a complementary relationship (e.g., Carvalho \& Schiozer, 2015; Vaidya, 2011; Fisman \& Raturi, 2004). Access to other external sources for financing working capital 
- credit from moneylenders (MLNDER), microfinance institutions (MFI), banks (BANKS) and friends (FRNDS) - are thus included in the econometric analysis.

To control for owners' characteristics, the age, sex, marital status, educational status and formal employment status of firms' largest owners are included. Firms with largest owners being older may suggest higher repayment ability as they may be relatively experienced in the business and are more likely to fulfil contractual obligations following receipt of trade credit. In general, since females appear to be more risk averse than males, they are less likely to engage in moral hazard behavior after receiving trade credit. This should thus increase their access to trade credit. However, in a study in Kenya and Zimbabwe, Fafchamps (2000) found femaleheaded firms having less access to supplier credit. Similar to the argument put forward for gender, firms' largest owners who are married may be perceived to be less risky by lenders. They are therefore more likely to receive trade credit from input suppliers upstream and/or customers downstream.

According to Issakson (2002), education level suggests managerial ability and thus ability to fulfill trade credit contractual obligations. Therefore, firms' access to trade credit may increase with the education level of the largest owners. The caveat is that, firms' largest owners with higher level of education may have access to other external sources of credit (e.g., banks) and may depend less on input suppliers and customers for working capital. Issakson (2002) argue that the relationship between educational status of a firm's staff and access to advanced payment is likely to be negative as such firms are less likely to face financial difficulties. Empirically, Issakson (2002) found educational level of staff to be significant and positive determinant of the amount of supplier credit and prepayment among Kenyan manufacturing firms. Firms whose largest owners have formal employment may rely less on suppliers and customers to finance their operations since earnings from the formal sector can be used to finance their business operations; they are also likely to have better access to formal credit from banks. However, suppliers/ customers may view such firms as having higher repayment ability and thus will be more willing to extend trade credit to them.

Finally, to control for the industrial sector firms operate, SECTR is included. SECTR is 1 if a firm is in manufacturing sector and o if services sector. The data were collected in four locations in Ghana - Tema, Takoradi, Accra and North (Kumasi and Tamale) of Ghana. These locations are included to control for location differences that may affect access to trade credit. 
Table 1: Variables, description and measurement

\begin{tabular}{|c|c|c|}
\hline Variable & Description & Measurement \\
\hline $\begin{array}{l}\text { TC } \\
\text { CLUSTR }\end{array}$ & $\begin{array}{l}\text { Access to trade credit } \\
\text { Industrial cluster }\end{array}$ & $\begin{array}{l}1 \text { if firm received trade credit from input suppliers } \\
\text { upstream and /or customers downstream and o } \\
\text { otherwise } \\
1 \text { if firm is located in an industrial cluster and o } \\
\text { otherwise }\end{array}$ \\
\hline CNTRACT & Production/supply contract & $\begin{array}{l}1 \text { if firm is producing/supplying under contract } \\
\text { and o otherwise }\end{array}$ \\
\hline $\ln F A G E$ & Age of firm & Natural logarithm of years of operation of firm \\
\hline $\operatorname{lnSALES}$ & Size of firm & Natural logarithm of past month sales \\
\hline NOWNRS & Firm ownership & Number of owners of firm \\
\hline OWNL & Ownership of location & 1 if firm own business location and o otherwise \\
\hline MLNDER & Money lender & $\begin{array}{l}1 \text { if firm obtained working capital from } \\
\text { moneylender for the past year and o otherwise }\end{array}$ \\
\hline MFI & Microfinance institution & $\begin{array}{l}1 \text { if firm obtained working capital from } \\
\text { microfinance institution for the past year and o } \\
\text { otherwise }\end{array}$ \\
\hline BANKS & Banks & $\begin{array}{l}1 \text { if firm obtained working capital from banks for } \\
\text { the past year and o otherwise }\end{array}$ \\
\hline FRNDS & Friends & $\begin{array}{l}1 \text { if firm obtained working capital from friends for } \\
\text { the past year and o otherwise }\end{array}$ \\
\hline FMALE & Sex of firm's largest owner & 1 if firm's largest owner is female and o otherwise \\
\hline $\ln A G E$ & Age of firm's largest owner & Natural logarithm of age of firm's largest owner \\
\hline FORMAL & $\begin{array}{l}\text { Formal employment status of } \\
\text { firm's largest owner }\end{array}$ & $\begin{array}{l}1 \text { if a firm's largest owner is engaged in a formal } \\
\text { employment and o otherwise }\end{array}$ \\
\hline MARRD & \multirow{3}{*}{$\begin{array}{l}\text { Marital status of firm's largest } \\
\text { owner } \\
\text { Marital status of firm's largest } \\
\text { owner } \\
\text { Marital status of firm's largest } \\
\text { owner }\end{array}$} & MARRD is 1 if married and o otherwise \\
\hline SNGLE & & SNGLE is 1 if single and o otherwise \\
\hline WIDOW & & WIDOW is 1 if widowed and o otherwise \\
\hline NEDU & \multirow{5}{*}{$\begin{array}{l}\text { Educational status of firm's } \\
\text { largest owner } \\
\text { Educational status of firm's } \\
\text { largest owner } \\
\text { Educational status of firm's } \\
\text { largest owner } \\
\text { Educational status of firm's } \\
\text { largest owner } \\
\text { Educational status of firm's } \\
\text { largest owner }\end{array}$} & NEDU is equal to 1 if no education and o otherwise \\
\hline PEDU & & $\begin{array}{l}\text { PEDU is equal to } 1 \text { if primary education and o } \\
\text { otherwise }\end{array}$ \\
\hline SEDU & & $\begin{array}{l}\text { SEDU is equal to } 1 \text { if secondary education and o } \\
\text { otherwise }\end{array}$ \\
\hline VOEDU & & $\begin{array}{l}\text { VOEDU is equal to } 1 \text { if vocational education and o } \\
\text { otherwise }\end{array}$ \\
\hline UNEDU & & $\begin{array}{l}\text { UNEDU is equal to } 1 \text { if university education and o } \\
\text { otherwise }\end{array}$ \\
\hline
\end{tabular}




\begin{tabular}{|c|c|c|}
\hline Variable & Description & Measurement \\
\hline SECTR & Industry category of firm & $\begin{array}{l}1 \text { if firm is in the manufacturing sector and o if } \\
\text { service sector }\end{array}$ \\
\hline TEMA & \multirow{4}{*}{$\begin{array}{l}\text { Geographical location } \\
\text { of firm } \\
\text { Geographical location } \\
\text { of firm } \\
\text { Geographical location } \\
\text { of firm } \\
\text { Geographical location }\end{array}$} & $\begin{array}{l}\text { TEMA is equal to } 1 \text { if firm is located in Tema and o } \\
\text { otherwise }\end{array}$ \\
\hline TKDI & & $\begin{array}{l}\text { TKDI is equal to } 1 \text { if firm is located in Takoradi and } \\
\text { o otherwise }\end{array}$ \\
\hline NORTH & & $\begin{array}{l}\text { NORTH is equal to } 1 \text { if firm is located in North and } \\
\text { o otherwise }\end{array}$ \\
\hline ACRA & & $\begin{array}{l}\text { ACRA is equal to } 1 \text { if firm is located in Accra and o } \\
\text { otherwise }\end{array}$ \\
\hline
\end{tabular}

\section{Econometric Model}

In this paper, the determinants of access to trade credit is modelled as probit. The dependent variable, access to trade credit is dichotomous; 1 if a firm received inputs from suppliers on credit and /or received advanced payment from customers in the past year and o otherwise. Let $\mathrm{y}^{*}$ be a continuous variable, representing the latent (unobserved) propensity to access trade credit. The $\mathrm{y}^{*}$ is assumed to be linearly related to observed predictor variables, expressed as:

$$
y_{\mathrm{i}}^{*}=\boldsymbol{\beta}^{\prime} \mathbf{x}_{\mathrm{i}}+\varepsilon_{\mathrm{i}}
$$

where $\boldsymbol{\beta}$ is a vector of parameters to be estimated, $\mathbf{x}$ is a vector of predictor variables predicting access to trade credit and $\varepsilon_{\mathrm{i}}$ is the error term. As $\mathrm{y}^{*}$ cannot be observed, but y (whether a firm has access to trade credit or not) is observed. The relationship between $y_{i}^{*}$ and $y_{i}$ is shown by the expression:

$$
y_{i}= \begin{cases}1 & \text { if } y_{\mathrm{i}}^{*}>0 \\ 0 & \text { if } \mathrm{y}_{\mathrm{i}}^{*} \leq 0\end{cases}
$$

where $\mathrm{y}_{\mathrm{i}}^{*}$ values are positive, $y_{i}=1$ for all those cases and where $\mathrm{y}_{\mathrm{i}}{ }^{*}$ assumes zero or negative values, $y_{i}=0$ for all those cases.

$\operatorname{Pr}\left(y_{i}=1 \mid \mathbf{x}_{\mathbf{i}}\right)=F\left(\boldsymbol{\beta}^{\prime} \mathbf{x}_{\mathbf{i}}\right)$

where $F$ is the cumulative distribution function (cdf) for the error term $\varepsilon_{i}$. For Probit model, $\varepsilon_{\mathrm{i}}$ is normally distributed, hence $F$ is a normal cdf (Greene, 2002).

$\operatorname{Pr}\left(y_{i}=1 \mid \mathbf{x}_{\mathbf{i}}\right)=\Phi\left(\boldsymbol{\beta}^{\prime} \mathbf{x}_{\mathbf{i}}\right)=\int_{-\infty}^{\boldsymbol{\beta}^{\prime} \mathbf{x}_{\mathbf{i}}} \emptyset(t) d t$

where $\emptyset(t)$ is the standard normal distribution. The marginal effect of change in $\mathbf{x}_{\mathrm{i}}$ on $y_{i}$ is given by: 


$$
\frac{\partial \mathrm{E}\left(\mathrm{y}_{\mathrm{i}} \mid \mathbf{x}_{\mathrm{i}}\right)}{\partial \mathbf{x}_{\mathrm{i}}}=\frac{\partial \mathrm{E}\left(\Phi\left(\boldsymbol{\beta}^{\prime} \mathbf{x}_{\mathrm{i}}\right)\right)}{\partial \mathbf{x}_{\mathrm{i}}}=\Phi\left(\boldsymbol{\beta}^{\prime} \mathbf{x}_{\mathrm{i}}\right) \boldsymbol{\beta}
$$

(Greene, 2002; Maddala, 1983).

The empirical Probit model for this paper is expressed as:

$$
\begin{aligned}
\operatorname{Pr}\left(\text { TC }_{i}=1\right) & =\beta_{0}+\beta_{1} \text { CLUSTR }_{\mathrm{i}}+\beta_{2} \text { CNTRACT }_{\mathrm{i}}+\beta_{3} \operatorname{lnFAGE}_{\mathrm{i}}+\beta_{4} \text { InSALES }_{\mathrm{i}} \\
& +\beta_{5} \text { NOWNRS }_{\mathrm{i}}+\beta_{6} \text { OWNL }_{\mathrm{i}}+\beta_{7} \text { MLNDER }_{\mathrm{i}}+\beta_{8} \text { MFI }_{\mathrm{i}}+\beta_{9} \text { BANKS }_{\mathrm{i}} \\
& +\beta_{10} \text { FRNDS }_{\mathrm{i}}+\beta_{11} \text { FMALE }_{\mathrm{i}}+\beta_{12} \operatorname{lnAGE}_{\mathrm{i}}+\beta_{13} \text { FORMAL }_{\mathrm{i}} \\
& +\beta_{14} \text { SNGLE }_{\mathrm{i}}+\beta_{15} \text { WIDOW }_{\mathrm{i}}+\beta_{16} \text { NEDU }_{\mathrm{i}}+\beta_{17} \text { PEDU }_{\mathrm{i}}+\beta_{18} \text { SEDU }_{\mathrm{i}} \\
& +\beta_{19} \text { VOEDU }_{\mathrm{i}}+\beta_{20} \text { SECTR }_{\mathrm{i}}+\beta_{21} \text { TEMA }_{\mathrm{i}}+\beta_{22} \text { TKDI }_{\mathrm{i}}+\beta_{23} \text { NRTH }_{\mathrm{i}} \\
& +\varepsilon_{i}
\end{aligned}
$$

where $\beta_{o}$ is the constant term, $\beta_{i}$ 's are parameters to be estimated, $X_{i}^{\prime}$ s are independent variables affecting access to trade credit from a firm's suppliers and/ or customers and $\varepsilon_{i}$ is the error term. All other variables are as defined in Table 1. MARRD, UNEDU and ACRA are used as reference category for marital status, educational status and geographical location respectively. They are thus excluded from the model to avoid dummy variable trap.

\section{Results and Discussion}

\section{Descriptive Analysis}

The descriptive statistics of variables used in the analysis are presented in Table 2. About $11.2 \%$ of the sample have access to trade credit from input suppliers upstream and/or customers downstream. Firms located in industrial clusters constitutes about $23.3 \%$ of the sample while about $16 \%$ of firms hold contract to produce or supply goods/services. The average firm in the sample is 10 years old. This result suggests the firms are relatively young. The average monthly sales of firms are around GHS $1,400^{23}$. This indicates many of the firms in the informal sector in Ghana are small in size. Relative to large and medium firms, small firms are more likely to suffer from credit rationing in financial markets (García-Teruel \& Martínez-Solano, 2010); they may therefore rely more on informal sources of external finance.

23 GHS stands for Ghana cedi, the official currency for Ghana. Using the average exchange rate of GHS1.954 to US\$1 in 2013 (see https://data.worldbank.org), it is about US\$716.450 per month. 
The number of owners of firms in the sample range from 1 to 11 , with an average of 1 owner. This indicates majority of the firms are sole proprietorship type of business organisations. About $27 \%$ of firms in the sample own the location they are situated. Since ownership of location is an asset to the firm, it can serve as collateral or implicit guarantee for accessing trade credit. Besides trade credit, other external sources for financing working capital include loans from moneylenders, microfinance institutions, banks, and friends. About 3\%, 8\%, 4\% and $11 \%$ of firms received working capital funding from moneylenders, microfinance institutions, banks, and friends respectively. Trade credit (11.2\%) thus ranks first in terms of external sources of financing working capital among informal firms while banks (4\%) and moneylenders (3\%) rank the least. In general, the results show that trade credit and credit from friends are the major external sources for financing working capital among informal firms. Firms may not be required to pay interest on trade credit (in the case of prepayment type of trade credit, Daripa and Nilsen (2011) states that it is pure cash advance with zero interest charged) and financial support from friends, making these sources cheaper sources for financing working capital relative to the other external sources where interests are charged on credit.

Majority of the firms have largest owners who are female (about 63\%) and are aged 39 years on average. However, only about $4 \%$ hold employment in the formal sector. Firms' largest owners who hold employment in the formal sector are likely to rely less on external sources for financing working capital. Majority of the firms' largest owners are married, about $65 \%$. In relation to educational status of the largest owners of firms, many of them have primary education (45\%), followed by secondary education (30\%). University education represents the least educational status attained, accounting for only $4 \%$. The firms are distributed equally between manufacturing and services. The descriptive statistics by trade credit status of firms are presented in Table A 1 in the appendix. 
Table 2: Summary statistics

\begin{tabular}{|c|c|c|c|c|c|}
\hline Variable & $\mathbf{N}$ & Mean & Std. Dev. & Minimum & Maximum \\
\hline $\mathrm{TC}$ & 726 & .112 & .315 & 0 & 1 \\
\hline CLUSTR & 681 & .233 & .423 & $\mathrm{o}$ & 1 \\
\hline CNTRACT & 726 & .156 & .363 & $\mathrm{o}$ & 1 \\
\hline FAGE & 711 & 9.624 & 9.274 & 1 & 132 \\
\hline SALES & 638 & 1400.027 & 2600.856 & 20 & 40000 \\
\hline NOWNRS & 729 & 1.158 & .645 & 1 & 11 \\
\hline OWNL & 652 & .271 & .445 & o & 1 \\
\hline MLNDER & 724 & .026 & .160 & 0 & 1 \\
\hline MFI & 723 & .084 & .278 & 0 & 1 \\
\hline BANKS & 724 & .040 & .196 & o & 1 \\
\hline FRNDS & 723 & .108 & .310 & o & 1 \\
\hline FMALE & 729 & .628 & .484 & 0 & 1 \\
\hline AGE & 714 & 39.450 & 11.350 & 18 & 80 \\
\hline FORMAL & 723 & .043 & .203 & o & 1 \\
\hline MARRD & 728 & .646 & .479 & 0 & 1 \\
\hline SNGLE & 728 & .235 & .424 & $\mathrm{o}$ & 1 \\
\hline WIDOW & 728 & .120 & .325 & 0 & 1 \\
\hline NEDU & 729 & .117 & .321 & 0 & 1 \\
\hline PEDU & 729 & .450 & .498 & 0 & 1 \\
\hline SEDU & 729 & .300 & .459 & o & 1 \\
\hline VOEDU & 729 & .081 & .273 & 0 & 1 \\
\hline UNEDU & 729 & .043 & .202 & 0 & 1 \\
\hline SECTR & 729 & .501 & .500 & 0 & 1 \\
\hline TEMA & 729 & .252 & .435 & 0 & 1 \\
\hline TKDI & 729 & .247 & .432 & 0 & 1 \\
\hline NRTH & 729 & .259 & .439 & o & 1 \\
\hline ACRA & 729 & .241 & .428 & $\mathrm{o}$ & 1 \\
\hline
\end{tabular}

Note: Actual values of firm age (FAGE), total sales (Sales) and largest owner's age (Age) are used in the descriptive analysis. In the correlation and econometric analysis, the natural logarithmic values are used.

The correlation matrix of the variables is presented in Table 3. The Pearson correction coefficients range from .0oo to .593. The correlation between most variables is below .30. The low correlations suggest that in the econometric estimations, multicollinearity problems will not be a concern. 
Table 3: Correlation matrix

\begin{tabular}{|c|c|c|c|c|c|c|c|c|c|c|c|c|c|c|}
\hline & 1 & 2 & 3 & 4 & 5 & 6 & 7 & 8 & 9 & 10 & 11 & 12 & 13 & 14 \\
\hline 1. TC & 1 & & & & & & & & & & & & & \\
\hline 2. CLUSTR & $.131^{*}$ & 1 & & & & & & & & & & & & \\
\hline 3. CNTRACT & $.149^{*}$ & $.112^{*}$ & 1 & & & & & & & & & & & \\
\hline 4. $\ln$ FAGE & $.103^{*}$ & .006 & $.132^{*}$ & 1 & & & & & & & & & & \\
\hline 5. $\operatorname{lnSALES}$ & .063 & $.107^{*}$ & $.177^{*}$ & $.120^{*}$ & 1 & & & & & & & & & \\
\hline 6. NWNRS & .049 & .045 & .037 & .046 & -.010 & 1 & & & & & & & & \\
\hline 7. OWNL & $-.086^{*}$ & -.068 & .019 & .006 & -.048 & .070 & 1 & & & & & & & \\
\hline 8. MLNDER & .025 & .038 & .001 & .051 & .006 & -.000 & .014 & 1 & & & & & & \\
\hline 9. MFI & .036 & -.017 & -.048 & .037 & .065 & -.043 & .067 & .019 & 1 & & & & & \\
\hline 10. BANKS & .018 & -.045 & $.106^{*}$ & $.105^{*}$ & $.108^{*}$ & -.017 & -.020 & -.033 & .039 & 1 & & & & \\
\hline 11. FRNDS & $.093^{*}$ & -.000 & -.014 & -.056 & -.036 & -.009 & $.087^{*}$ & .055 & -.024 & -.001 & 1 & & & \\
\hline 12. FMALE & -.009 & .034 & $-.165^{*}$ & $-.162^{*}$ & $-.147^{*}$ &.$- .080^{*}$ & -.022 & -.017 & .046 & -.005 & -.021 & 1 & & \\
\hline 13. $\ln A G E$ & $.075^{*}$ & -.062 & .013 & $.366^{*}$ & $.096^{*}$ & .003 & .040 & .018 & .071 & $.075^{*}$ & -.056 & $.083^{*}$ & 1 & \\
\hline 14. FORMAL & -.008 & -.010 & -.016 & $-.085^{*}$ & .017 & .001 & -.044 & -.034 & -.037 & .066 & .020 & -.050 & .031 & 1 \\
\hline 15. MARRD & .072 & -.070 & .071 & $.076^{*}$ & .026 & -.038 & .043 & .032 & .008 & .060 & -.001 & -.072 & $.146^{*}$ & .072 \\
\hline 16. SNGLE & $-.125^{*}$ & .021 & -.030 & $-.155^{*}$ & -.060 & .051 & -.013 & -.051 & -.052 & -.061 & .048 & $-.096^{*}$ & $-.412^{*}$ & -.053 \\
\hline 17. WIDOW & .058 & $.076^{*}$ & -.065 & $.092^{*}$ & .039 & -.011 & -.047 & .019 & .056 & -.008 & -.060 & $.231^{*}$ & $.321^{*}$ & -.036 \\
\hline 18. NEDU & $.102^{*}$ & -.003 & -.038 & -.016 & $-.086^{*}$ & -.036 & -.036 & .022 & -.018 & -.031 & -.002 & $.209^{*}$ & $.154^{*}$ & -.056 \\
\hline 19. PEDU & .004 & -.031 & $-.097^{*}$ & $.074^{*}$ & -.003 & -.008 & .032 & $.094^{*}$ & .023 & -.002 & -.020 & .057 & -.009 & $-.138^{*}$ \\
\hline 20. SEDU & -.069 & -.012 & .059 & -.000 & .046 & -.040 & -.034 & -.069 & -.012 & -.041 & .046 & $-.140^{*}$ & $-.109^{*}$ & -.049 \\
\hline 21. VOEDU & $-.089^{*}$ & .052 & .039 & -.061 & -.025 & $.091^{*}$ & .039 & -.049 & .000 & -.035 &.- .071 & -.011 & -.047 & .063 \\
\hline 22. UNEDU & $.077^{*}$ & .043 & $.116^{*}$ & -.045 & .061 & .043 & .007 & -.035 & -.015 & $.166^{*}$ & .036 & $-.133^{*}$ & .068 & $.360^{*}$ \\
\hline 23. SECTR & $.081^{*}$ & .009 & $.100^{*}$ & $.150^{*}$ & $.091^{*}$ & .032 & .030 & -.027 & -.017 & -.009 & -.002 & -.042 & $.079^{*}$ & -.063 \\
\hline 24. TEMA & -.025 & $.374^{*}$ & $-.076^{*}$ & $-.096^{*}$ & $.108^{*}$ & $-.098^{*}$ & $-.116^{*}$ & .063 & $-.086^{*}$ & -.055 & -.029 & $.114^{*}$ & -.016 & $-.091^{*}$ \\
\hline 25. TKDI & -.031 & $-.087^{*}$ & $-.139^{*}$ & -.003 & $-.130^{*}$ & -.017 & .034 & -.055 & .032 & .029 & .027 & $.157^{*}$ & .012 & .069 \\
\hline 26. NRTH & .073 & $-.091^{*}$ & $.154^{*}$ & $.114^{*}$ & -.074 & $.132^{*}$ & .064 & -.037 & $.085^{*}$ & $.075^{*}$ & .043 & $-.322^{*}$ & -.031 & .046 \\
\hline 27. ACRA & -.017 & $-.197^{*}$ & .059 & -.017 & $.090^{*}$ & -.019 & .015 & .028 & -.032 & -.050 & -.040 & .056 & .035 & -.024 \\
\hline
\end{tabular}

Note: ${ }^{*}$ Indicates correlation coefficients with p-values of .o5 or lower 
Table 3: Correlation matrix (Continued)

\begin{tabular}{|c|c|c|c|c|c|c|c|c|c|c|c|c|c|}
\hline & 15 & 16 & 17 & 18 & 19 & 20 & 21 & 22 & 23 & 24 & 25 & 26 & 27 \\
\hline 15. MARRD & 1 & & & & & & & & & & & & \\
\hline 16. SNGLE & $-.075^{*}$ & 1 & & & & & & & & & & & \\
\hline 17. WIDOW & $-.500^{*}$ & $-.204^{*}$ & 1 & & & & & & & & & & \\
\hline 18. NEDU & .010 & $-.111^{*}$ & $.130^{*}$ & 1 & & & & & & & & & \\
\hline 19. PEDU & -.018 & .001 & .025 & $-.329^{*}$ & 1 & & & & & & & & \\
\hline 20. SEDU & -.002 & .061 & $-.076^{*}$ & $-.238^{*}$ & $-.593^{*}$ & 1 & & & & & & & \\
\hline 21. VOEDU & -.022 & .049 & -.032 & $-.108^{*}$ & $-.268^{*}$ & $-.195^{*}$ & 1 & & & & & & \\
\hline 22. UNEDU & .057 & -.021 & -.057 & $-.077^{*}$ & $-.191^{*}$ & $-.138^{*}$ & -.063 & 1 & & & & & \\
\hline 23. SECTR & .043 & $-.076^{*}$ & .037 & $.124^{*}$ & .026 & -.064 & .005 & $-.102^{*}$ & 1 & & & & \\
\hline 24. TEMA & -.045 & .021 & .039 & -.014 & $.090^{*}$ & -.057 & .001 & $-.076^{*}$ & .006 & 1 & & & \\
\hline 25. TKDI & -.008 & -.017 & .034 & .040 & -.051 & .006 & .040 & .005 & -.007 & $-.333^{*}$ & 1 & & \\
\hline 26. NRTH & .122 & -.016 & $-.159^{*}$ & -.039 & -.038 & .036 & -.072 & $.155^{*}$ & .009 & $-.344^{*}$ & -.339 & 1 & \\
\hline 27. ACRA & -.071 & .013 & $.089^{*}$ & .015 & -.001 & .015 & .032 & $-.087^{*}$ & -.007 & $-.328^{*}$ & $-.323^{*}$ & $-.334^{*}$ & 1 \\
\hline
\end{tabular}

Note: *Indicates correlation coefficients with p-values of .05 or lower 


\section{Determinants of Access to Trade Credit}

The probit results of determinants of access to trade credit are presented in Table 4. Marginal effects $(\mathrm{dy} / \mathrm{dx})$ are reported, with corresponding robust standard errors. The regression model is statistically significant at the $1 \%$ level as shown by the Wald Chi-Squared statistic reported at the bottom of the table.

The explanatory variables, CLUSTR and CNTRACT are significant in explaining access to trade credit. The positive and significant effect of CLUSTR suggest that locating in an industrial cluster increases access to trade credit from suppliers upstream and/or customers downstream. There is 0.087 marginal effect of locating in an industrial cluster on access to trade credit. The results indicate that the close proximity and frequent interaction that exists among firms in industrial clusters serves to reduce information asymmetry and increase trade credit activity. This finding thus validates the first stated hypothesis of this study (Hypothesis 1). This finding also confirms findings from Long and Zhang (2011) and Ruan and Zhang (2008) independent studies in China, where industrial clusters were found to facilitate access to trade credit. Holding a production or supply contract has a positive and significant effect on access to trade credit, at the $5 \%$ significance level. The marginal effect of holding production/supply contract on access to trade credit is 0.079 . This result validates hypothesis 2 of this study. As noted earlier, a firm that has a contract to produce/supply goods may require prior commitment from the buyer in the form of deposit or advanced payment ex ante to reduce possible opportunism from the buyer ex post. Trade credit may thus be part of the contractual terms. Also, a firm holding a production/supply contract signals to input suppliers upstream that it is reputable, which increases access to trade credit. The production/ supply contract can serve as implicit guarantee, based on which trade credit can be advanced by input suppliers upstream.

The significant control variables are lnFAGE, NOWNRS, OWNL, external sources of funds (BANKS and FRNDS), FORMAL, marital status (SNGLE), and education variables (NEDU, PEDU, SEDU and VOEDU). The probability of accessing trade credit increases with firm age. There is 0.040 marginal effect of an additional year of a firm's existence on access to trade credit. In related studies, Petersen and Rajan (1997), Kihanga et al. (2010) and García-Teruel and Martínez-Solano (2010) also found positive association between firm age and receipt of trade credit. At 5\% level of significance, access to trade credit increases with the number of owners of a firm. The results suggest that suppliers upstream and buyers downstream are more willing to extend trade credit to firms with many owners, perhaps due to their low risks profile relative to sole proprietorship type of firms. Against a prior expectation, the relationship between ownership of business location and access 
to trade credit is negative. Since ownership of business location is an asset that can serve as collateral or guarantee, it was expected that, it will facilitate receipt of more trade credit. However, enterprises owning the locations of their businesses could use them as collateral for loans from financial institutions and hence may not have need for trade credit.

The results on external financing control variables (MLNDR, BANKS, MFI, FRNDS) indicate that only BANKS and FRNDS have significant relationship with access to trade credit. BANKS have negative relationship with trade credit at 1\% significance level. The negative marginal effect suggest that bank loans and trade credit are substitutes $^{24}$ when it comes to external financing sources for working capital. It means access to bank loans reduces the need for trade credit. In related studies, García-Teruel and Martínez-Solano (2010) and Kwenda and Holden (2014) found similar results. On the contrary, the relationship between FRNDS and trade credit is significant and positive at $1 \%$ level of significance. The results suggest firms may be using trade credit to supplement loans from friends, perhaps due to the inadequacy of the loan amounts they receive from friends. Another dimension is that, credit from friends can be used to make part payment (or deposit) for goods, thereby increasing access to trade credit.

Firms whose main owners hold employment in the formal sector receive less trade credit as shown by a significant and negative relationship between access to trade credit and FORMAL. The results can be interpreted to mean that, firms' largest owners with formal employment status may have no need for credit from input suppliers and customers to finance working capital since earnings from the formal sector can be used for that purpose. Relative to married largest owners of firms, largest owners who are single have less access to trade credit. This finding is similar to what Kihanga et al. (2010) found among Tanzanian rice traders. The other marital status variable, WIDOW, has no relationship with access to trade credit relative to being married.

Finally, on the largest owners' education, NEDU, PEDU, SEDU, and VOEDU all have negative and significant relationship with access to trade credit relative to UNEDU (reference category). The results suggest that a firm with largest owner having university education increases access of the firm to trade credit relative to firms whose largest owners have no education, primary education, secondary education, and vocational education. This may be due to higher reputation and creditworthiness associated with higher educational qualifications.

24 However, trade credit and bank loans may be imperfect substitutes due to differences in the credit characteristics. 
Table 4: Determinants of access to trade credit (Probit Results)

\begin{tabular}{|c|c|c|}
\hline & $d y / d x$ & Std. Err. \\
\hline CLUSTR & $.087^{* *}$ & .038 \\
\hline CNTRACT & $.079^{*}$ & .043 \\
\hline $\operatorname{lnFAGE}$ & $.040^{* *}$ & .016 \\
\hline lnSALES & .008 & .009 \\
\hline NOWNRS & $.036^{* *}$ & .016 \\
\hline OWNL & $-.073^{* * *}$ & .018 \\
\hline MLNDER & .005 & .056 \\
\hline MFI & .059 & .051 \\
\hline BANKS & $-.060^{* * *}$ & .018 \\
\hline FRNDS & $.128^{* *}$ & .056 \\
\hline FMALE & .012 & .023 \\
\hline $\ln A G E$ & -.033 & .047 \\
\hline FORMAL & $-.066^{* * *}$ & .017 \\
\hline SNGLE & $-.061^{* * *}$ & .022 \\
\hline WIDOW & .013 & .037 \\
\hline NEDU & $-.063^{* * *}$ & .024 \\
\hline PEDU & $-.133^{* *}$ & .053 \\
\hline SEDU & $-.134^{* * *}$ & .036 \\
\hline VOEDU & $-.095^{* * *}$ & .017 \\
\hline SECTR & .017 & .022 \\
\hline TEMA & -.027 & .030 \\
\hline TKDI & -.008 & .031 \\
\hline NRTH & -.012 & .028 \\
\hline Constant & -.736 & 1.475 \\
\hline Pseudo R2 & .202 & .202 \\
\hline Wald Chi2 & $68.45^{* * *}$ & $68.45^{* * *}$ \\
\hline $\mathrm{N}$ & 546 & 546 \\
\hline
\end{tabular}

Note: The dependent variable (TC) takes the value of 1 if firm has access to trade credit in the past year and o otherwise. All other variables are defined in Table 1. The reported standard errors are robust standard errors. ${ }^{* *}{ }^{*}$, and ${ }^{* *}$ indicates significance at $10 \%, 5 \%$ and $1 \%$ level respectively. 


\section{Robustness Checks}

To check the robustness of the results presented in Table 4, an alternative measure of firm size is introduced. Due to the fact that sales vary with season, lnSALES (natural logarithm of past month sales) is replaced with lnAVSALES, natural logarithm of average monthly sales during regular season, busiest season and slowest season of the year25. As shown in Table 5, the results are similar to those presented in Table 4. The independent variables, CLUSTR and CNTRACT significantly determine access to trade credit among firms in the informal sector while firm size as measured by InAVSALES is still insignificant.

25 The questionnaire was designed to capture sales during regular, busiest and slowest months of the year. 
Table 5: Robustness checks

\begin{tabular}{|c|c|c|}
\hline & $\mathrm{dy} / \mathrm{dx}$ & Std. Err. \\
\hline CLUSTR & $.084^{* *}$ & .037 \\
\hline CNTRACT & $.088^{* *}$ & .044 \\
\hline $\operatorname{lnFAGE}$ & $.039^{* *}$ & .016 \\
\hline lnAVSALES & .000 & .009 \\
\hline NOWNRS & $.036^{* *}$ & .016 \\
\hline OWNL & $-.075^{* * *}$ & .018 \\
\hline MLNDER & .007 & .058 \\
\hline MFI & .061 & .052 \\
\hline BANKS & $-.059^{* * *}$ & .020 \\
\hline FRNDS & $.127^{* *}$ & .057 \\
\hline FMALE & .014 & .023 \\
\hline $\ln A G E$ & -.029 & .047 \\
\hline FORMAL & $-.066^{* * *}$ & .017 \\
\hline SNGLE & $-.062^{* * *}$ & .022 \\
\hline WIDOW & .012 & .037 \\
\hline NEDU & $-.065^{* * *}$ & .024 \\
\hline PEDU & $-.138^{* *}$ & .054 \\
\hline SEDU & $-.135^{* * *}$ & .033 \\
\hline VOEDU & $-.096^{* * *}$ & .017 \\
\hline SECTR & .017 & .022 \\
\hline TEMA & -.023 & .030 \\
\hline TKDI & -.009 & .030 \\
\hline NRTH & -.014 & .028 \\
\hline Constant & -.473 & 1.462 \\
\hline Wald Chi2 & $65.03^{* * *}$ & \\
\hline Pseudo R2 & .200 & \\
\hline $\mathrm{N}$ & 546 & \\
\hline
\end{tabular}

Note: The dependent variable (TC) takes the value of 1 if firm has access to trade credit in the past year and o otherwise, $\ln$ AVSALES is natural logarithm of average monthly sales during regular season, busiest season and slowest season. All other variables are defined in Table 1. The reported standard errors are robust standard errors. ${ }^{* *}$ and ${ }^{* * *}$ indicates significance at $5 \%$ and $1 \%$ level respectively. 


\section{Conclusion and Policy Suggestions}

This paper examines the role of locating in industrial cluster and holding production/ supply contract on access to trade credit from suppliers upstream and/or customers downstream among informal firms in Ghana. Hitherto, the role of these variables has not been examined in relation to access to trade credit in the informal sector. The study employed data from the 2013 World Bank survey of informal firms in Ghana. Only 11.2\% of firms in the sample have access to trade credit. Despite, access to trade credit is higher than all other external sources of financing working capital - moneylenders, banks, microfinance institutions and friends. Thus, trade credit is the most important source of external finance in relation to working capital in the informal sector. Probit analytical technique was employed to examine the effect of locating in industrial cluster and holding production/supply contract on access to trade credit, while controlling for firm characteristics, financial characteristics, firms' largest owners' characteristics, industrial sector and geographical location. The results show that both locating in industrial cluster and holding a production/supply contract increases access to trade credit by informal firms. Other variables significantly associated with access to trade credit by informal firms include firm age (+), number of owners $(+)$, ownership of location (-), access to bank loans (-), access to loans from friends $(+)$, formal employment status of largest owners (-), being single relative to being married (-), and all levels of education (no education, primary education, secondary education, vocational education) relative to university education $(-)^{26}$.

The data employed have some limitations. The framing of the question based on which the dependent variable was constructed does not permit distinction to be made between trade credit from suppliers upstream and trade credit from customers downstream. Therefore, the analysis could not be done separately for access to supplier credit and advanced payment but jointly. Also, information on the proportion of sales represented by advanced payment and proportion of input purchases on account are unavailable to permit analysis of the level of access to trade credit. Future research should address these limitations. Notwithstanding, the results has important policy implications. Policy should be focused on developing industrial clusters across Ghana, as industrial clusters helps informal firms to mitigate their credit constraint through increased access to trade credit. For start-up firms in particular, locating in industrial clusters could increase access to trade credit and other forms of informal finance through development of social capital via close proximity and frequent interaction between firms, suppliers and customers that characterises industrial clusters. Informal firms could also mitigate

26 The (-) and (+) are the signs of the marginal effects of the variables. 
their credit constraint via trade credit by actively seeking contracts to produce/ supply goods.

\section{References}

Akoten, J.E., Sawada, Y. and Otsuka, K. (2006). The determinants of credit access and its impacts on micro and small enterprises: The case of garment producers in Kenya. Economic Development and Cultural Change, 54(4), pp. 927-944.

Alarcón, L.S. (2011). The trade credit in the Spanish agrofood industry. Mediterranean Journal of Economics, Agriculture and Environment, 10(2), pp. 51-57.

Brennan M.V. Maksimovic and J. Zechner (1988). Vendor financing. Journal of Finance, 43(5), pp. 1127-1141.

Brick, I.E. and Fung, W. K. (1984). The effect of taxes on the trade credit decision. Financial Management, 13(2), pp. 24-30.

Brousseau, E., and Glachant, J. (2002). The Economics of Contracts and the Renewal of Economics. In Brousseau, E., and J. Glachant (Eds.), the Economics of ContractsTheories and Applications, pp. 3-30. Cambridge: Cambridge University Press.

Burkart, M. and Ellingsen, T. (2004). In-kind finance: A theory of trade credit. The American Economic Review, 94(3), 569-590.

Carvalho, C.J.D., and Schiozer, R.F. (2015). Determinants of Supply and Demand for Trade Credit by Micro, Small and Medium-Sized Enterprises. Revista Contabilidade and Finanças, 26(68), pp. 208-222.

Chandler, V. (2009). Determinants of trade credit use by small and medium-sized enterprises in Canada (Working paper). Ottawa, Canada: Government of Canada.

Cheng, N.S., and Pike, R. (2003). The trade credit decision: evidence of UK firms. Managerial and Decision Economics, 24(6-7), pp. 419-438.

Clarke, G.R., Cull, R., and Peria, M.S.M. (2006). Foreign bank participation and access to credit across firms in developing countries. Journal of Comparative Economics, 34(4), 774-795.

Cuevas, C., Fafchamps, M., Hanson, R., Moll, P. and Srivastava, P. (1993). Case Studies of Enterprise Finance in Ghana. RPED Case Study Series. Washington DC: The World Bank.

Daripa, A., and Nilsen, J. (2011). Ensuring sales: A theory of inter-firm credit. American Economic Journal: Microeconomics, 3(1), pp. 245-279. 
Dary, S.K. (2017). Three Essays on Trade Credit Theory and Empirical Evidence from

Agro-food Firms in Africa and United States. Doctoral Dissertation, University of Missouri-Columbia, USA.

Dary, S.K., and James, H. S. (2018). Trade credit supply in African agro-food manufacturing industry: determinants and motives. Agricultural Finance Review, 78(3), pp. 312-329.

Dinh, H.T., Rawski, T.G., and Zafar, A. (2013). Tales from the development frontier: How China and other countries harness light manufacturing to create jobs and prosperity. World Bank Publications.

Dyer, J.H. (1997). Effective interfirm collaboration: how firms minimise transaction costs and maximise transaction value. Strategic Management Journal, 18(7), 535-556.

Ellingsen, T., Jacobson, T., and von Schedvin, E.L. (2016). Trade credit: Contract-level evidence contradicts current theories. Sveriges Riksbank Working Paper Series, 315 .

Emery, G.W. (1984). A pure financial explanation for trade credit. Journal of Financial and Quantitative Analysis, 19(3), 271-285.

Fabbri, D. and Klapper, L. (2008). Trade credit supply, market power and the matching of trade credit terms. Policy research working paper no. 4754. Washington DC: The World Bank.

Fafchamps, M. (2000). Ethnicity and credit in African manufacturing. Journal of Development Economics, 61(1), pp. 205-235.

Fafchamps, M., Pender, J., and Robinson, E. (1995). Enterprise finance in Zimbabwe. RPED Case Study Series. Washington DC: The World Bank.

Ferris, J.S. (1981). A transactions theory of trade credit use. The Quarterly Journal of Economics, 96(2), pp. 243-270.

Fisman, R., and Raturi, M. (2004). Does competition encourage credit provision? Evidence from African trade credit relationships. Review of Economics and Statistics, 86(1), pp. 345-352.

Foghani, S., Mahadi, B., and Omar, R. (2017). Promoting Clusters and Networks for Small and Medium Enterprises to Economic Development in the Globalisation Era. SAGE Open, 7(1), pp. 1-9.

García-Teruel, P.J., and Martínez-Solano, P.M. (2010). Determinants of trade credit: a comparative study of European SMEs. International Small Business Journal, 28(3), pp. 215-233. 
Greene, W.H. (2002). Econometric Analysis. New Jersey: Prentice Hall.

Isaksson, A. (2002). Trade credit in Kenyan manufacturing: Evidence from plant-level data. SIN working paper series no.4, Austria: UNIDO.

Kihanga, E., Lensink, R., Lutz, C., and Hermes, N. (2010). Determinants of Trade Credit Demand and Supply in the Tanzanian Rice Market: A Structural Modelling Approach. Retrieved from http://ssrn.com/abstract=1674842.

Klapper, L., Laeven, L., and Rajan, R. (2012). Trade credit contracts. Review of Financial Studies, 25(3), pp. 838-867.

Kwenda, F., and Holden, M. (2014). Trade credit in corporate financing in South Africa: evidence from a dynamic panel data analysis. Investment Management and Financial Innovations, 11(4), pp. 268-278.

Lin, T.T., and Chou, J.H. (2015). Trade credit and bank loan: Evidence from Chinese firms. International Review of Economics and Finance, 36, pp. 17-29.

Little, R.J., and Rubin, D.B. (2014). Statistical analysis with missing data (Vol. 333). New Jersey: John Wiley and Sons.

Long, M.S., Malitz, I.B., and Ravid, A. (1993). Trade credit, quality guarantees, and product marketability. Financial Management, 22(4), pp. 117-127.

Long, C., and Zhang, X. (2011). Cluster-based industrialisation in China: Financing and performance. Journal of International Economics, 84(1), pp. 112-123.

Maddala, G.S. (1983). Limited-Dependent and Qualitative Variables in Econometrics. New York: Cambridge University Press.

Mateut, S. (2014). Reverse trade credit or default risk? Explaining the use of prepayments by firms. Journal of Corporate Finance, 29, pp. 303-326.

Mateut, S., and Zanchettin, P. (2013). Credit sales and advance payments: Substitutes or complements? Economics Letters, 118(1), pp. 173-176.

Meltzer, A.H. (1960). Mercantile credit, monetary policy, and size of firms. The Review of Economics and Statistics, 42(4), pp. 429-437.

Nadiri, M.I. (1969). The determinants of trade credit in the US total manufacturing sector. Econometrica: Journal of the Econometric Society, 37(3), pp. 408-423.

Ng, C. K., Smith, J. K., and Smith, R. L. (1999). Evidence on the determinants of credit terms used in interfirm trade. The Journal of Finance, 54(3), pp. 1109-1129.

Ogawa, K., Sterken, E., and Tokutsu, I. (2013). The trade credit channel revisited: evidence from micro data of Japanese small firms. Small Business Economics, 40(1), pp. 101-118. 
Petersen, M.A., and Rajan, R.G. (1997). Trade credit: theories and evidence. Review of Financial Studies, 10(3), pp. 661-691.

M.E. Porter (1998). Clusters and the New Economics of Competition. Harvard Business Review, 76(6), pp. 77-90.

Ruan, J., and Zhang, X. (2008). Finance and cluster-based industrial development in China. IFPRI discussion paper o0768. IFPRI: Washington DC.

Saito, R., and Bandeira, M. L. (2010). Empirical Evidence of Trade Credit Uses of Brazilian Publicly-Listed Companies. Brazilian Administration Review, 7(3), pp. 242-259.

Schwartz, R.A. (1974). An economic model of trade credit. Journal of Financial and Quantitative Analysis, 9(4), pp. 643-657.

Schwartz, R.A., and Whitcomb, D. K. (1978). The trade credit decision. Graduate School of Business Administration, New York University.

Smith, J.K. (1987). Trade credit and informational asymmetry. The Journal of Finance, 42(4), pp. 863-872.

Vaidya, R.R. (2011). The determinants of trade credit: Evidence from Indian manufacturing firms. Modern Economy, 2(5), pp. 707-716.

Van Horen, N. (2005). Trade credit as a competitiveness tool; evidence from developing countries: evidence from developing countries. Retrieved from https://mpra. ub.uni-muenchen.de/2792/1/MPRA_paper_2792.pdf.

Wheelen, T.L., and Hunger, J.D. (2012). Strategic management and business policy: towards global sustainability. New Jersey: Pearson Education Inc.

Wilner, B.S. (2000). The exploitation of relationships in financial distress: The case of trade credit. The Journal of Finance, 55(1), pp. 153-178.

Wilson, N., and Summers, B. (2002). Trade credit terms offered by small firms: survey evidence and empirical analysis. Journal of Business Finance and Accounting, 29(3-4), pp. 317-351.

Yang, S.A., and Birge, J.R. (2013). How inventory is (should be) financed: Trade credit in supply chains with demand uncertainty and costs of financial distress. Retrieved from https://papers.ssrn.com/sol3/papers.cfm?abstract_id=1734682.

Zhang, X. (2016). Building effective clusters and industrial parks. IFPRI Discussion Paper 01590. IFPRI: Washington DC. 


\section{Appendix 1}

Table A1: Descriptive statistics by trade credit status

\begin{tabular}{|c|c|c|c|c|c|c|}
\hline & \multicolumn{2}{|c|}{$\mathbf{T C}=1$} & \multirow[b]{2}{*}{ Std. Dev. } & \multicolumn{3}{|c|}{$\mathbf{T C}=\mathbf{0}$} \\
\hline & $\mathbf{N}$ & Mean & & $\mathbf{N}$ & Mean & Std. Dev. \\
\hline CLUSTR & 77 & .390 & .491 & 601 & .215 & .411 \\
\hline CNTRACT & 81 & .309 & .465 & 642 & .137 & .344 \\
\hline $\operatorname{lnFAGE}$ & 80 & 12.625 & 15.657 & 628 & 9.243 & 8.067 \\
\hline $\operatorname{lnSALES}$ & 74 & 1504.297 & 1669.580 & 564 & 1386.346 & 2700.095 \\
\hline NOWNRS & 81 & 1.247 & .699 & 645 & 1.147 & .639 \\
\hline OWNL & 77 & .169 & .377 & 572 & .287 & .453 \\
\hline MLNDER & 80 & .038 & .191 & 644 & .025 & .156 \\
\hline MFI & 80 & .113 & .318 & 643 & .081 & .273 \\
\hline BANKS & 80 & .050 & .219 & 644 & .039 & .193 \\
\hline FRNDS & 79 & .190 & .395 & 644 & .098 & .297 \\
\hline FMALE & 81 & .617 & .489 & 645 & .631 & .483 \\
\hline OAGE & 78 & 41.462 & 10.343 & 633 & 39.200 & 11.454 \\
\hline FORMAL & 81 & .037 & .190 & 639 & .043 & .201 \\
\hline MARRD & 81 & .741 & .441 & 644 & .632 & .483 \\
\hline SNGLE & 81 & .086 & .283 & 644 & .255 & .436 \\
\hline WIDOW & 81 & .173 & .380 & 644 & .113 & .317 \\
\hline NEDU & 81 & .210 & .410 & 645 & .105 & .307 \\
\hline PEDU & 81 & .457 & .501 & 645 & .451 & .498 \\
\hline SEDU & 81 & .210 & .410 & 645 & .310 & .463 \\
\hline VOEDU & 81 & .012 & .111 & 645 & .090 & .286 \\
\hline UNEDU & 81 & .086 & .283 & 645 & .037 & .189 \\
\hline SECTR & 81 & .617 & .489 & 645 & .488 & .500 \\
\hline TEMA & 81 & .222 & .418 & 645 & .257 & .438 \\
\hline TKDI & 81 & .210 & .410 & 645 & .253 & .435 \\
\hline NRTH & 81 & .346 & .479 & 645 & .245 & .430 \\
\hline ACRA & 81 & .222 & .418 & 645 & .245 & .430 \\
\hline
\end{tabular}

Note: $\mathrm{TC}=1$ represent firms with access to trade credit and $\mathrm{TC}=0$ represent firms without access to trade credit. 